\title{
Analisis Kemampuan Literasi Matematika ditinjau dari Gaya Belajar Siswa SMA
}

\author{
Edimuslim $^{1}$, Sofia Edriati ${ }^{2}$, Ainil Mardiyah ${ }^{3}$ \\ ${ }^{1}$ Pendidikan Matematika, STKIP PGRI Sumatera Barat \\ e-mail: ${ }^{1}$ edhye.sam.07@gmail.com
}

\begin{abstract}
ABSTRAK. Penelitian ini bertujuan untuk mendeskripsikan kemampuan literasi matematika siswa berdasarkan kompetensi Reproduksi, Koneksi dan Refleksi ditinjau dari gaya belajar siswa kelas XII MIA 3. Jenis penelitian yang digunakan adalah penelitian deskriptif dengan pendekatan kualitatif. Instrumen yang digunakan adalah angket gaya belajar dan tes kemampuan literasi matematika serta pedoman wawancara. Teknik analisis data yang digunakan adalah analisis tes gaya belajar dan analisis tes kemampuan literasi matematika dengan uji keabsahan data menggunakan triangulasi metode. Hasil penelitian ini menunjukkan bahwa; 1) Gaya belajar siswa yang dominan adalah Visual, Auditorial dan Kinestetik; 2) Siswa pada gaya belajar Visual dengan kompetensi Reproduksi kesulitan dalam menyatakan masalah kedalam matematika. Siswa dengan kompetensi Koneksi mampu memahami soal tetapi kesulitan dalam proses memilih strategi untuk memecahkan masalah. Siswa dengan kompetensi Refleksi mampu memenuhi semua indikator pada soal level 5; 3) Siswa pada gaya belajar Auditorial dengan kompetensi Reproduksi belum memenuhi proses menggunakan bahasa dan operasi simbolis. Siswa dengan kompetensi Koneksi mampu memenuhi indikator Komunikasi, matematisasi serta mampu menggunakan strategi untuk memecahkan masalah; 4) Siswa dengan gaya belajar Kinestetik dengan kompetensi Reproduksi belum memenuhi indikator proses komunikasi, matematisasi serta memilih strategi untuk memecahkan masalah. Siswa dengan kompetensi Koneksi mampu memenuhi indikator proses menggunakan alat-alat matematika, representasi, matematisasi serta memilih strategi pemecahan masalah.
\end{abstract}

Kata Kunci : Gaya Belajar, Kemampuan Literasi Matematika.

\section{PENDAHULUAN}

Pendidikan abad ke-21 menuntut semua orang mengembangkan seluruh kompetensi yang dimilikinya. Pendidikan melalui pembelajaran di sekolah pada abad ke-21 mempunyai paradigma pembelajaran yang menekankan kemampuan berpikir kritis, mampu menghubungkan ilmu dengan dunia nyata, menguasai teknologi informasi, berkomunikasi dan berkolaborasi. Hal ini akan terwujud apabila siswa memiliki kemampuan literasi matematika yang memadai. Kemampuan literasi matematika sangat penting untuk dimiliki oleh siswa karena, dapat membantu siswa menggunakan matematika dalam kehidupan nyata, menggunakan metode yang efisien untuk pemecahan masalah, melakukan penilaian apakah hasil yang diperoleh masuk akal serta menganalisis situasi dan menarik kesimpulan (Genc \& Erbas, 2019). Selain itu, literasi matematika juga menuntut siswa untuk mengkomunikasikan dan menjelaskan fenomena yang dihadapinya dengan konsep matematika. Hal ini sejalan dengan definisi literasi matematika yang merupakan kapasitas individu untuk memformulasikan, menggunakan, dan menafsirkan matematika dalam berbagai konteks. Kemampuan meliputi penalaran matematika dan menggunakan konsep, prosedur, fakta dan alat matematika untuk mendeskripsikan, menjelaskan, dan memprediksi fenomena(OECD, 2019). 
Terdapat tiga kelompok kompetensi kemampuan literasi matematika pada PISA yaitu kelompok Reproduksi, kelompok Koneksi dan kelompok Refleksi (Thomson, Hillman, \& Bortoli, 2013). Kelompok Reproduksi, siswa menafsirkan representasi sederhana dan permasalahan yang familiar, melakukan perhitungan sederhana dan prosedur untuk menyelesaikan masalah rutin. Kelompok Koneksi, siswa mengintegrasikan dan menghubungkan seluruh konten, situasi dan representasi penyelesaian masalah non rutin dengan menggunakan beberapa metode yang jelas dalam penalaran matematika yang sederhana. Kelompok Refleksi, siswa memecahkan masalah yang kompleks, menemukan ide tentang matematika, menggunakan banyak metode kompleks untuk membuat generalisasi dalam memecahkan masalah.

PISA mengembangkan enam level kategori kemampuan literasi matematika. Literasi matematika level 1 dan level 2 merupakan kelompok soal dengan skala paling bawah, literasi matematika level 2 dan level 3 merupakan soal dengan skala menengah dan literasi matematika level 5 dan level 6 merupakan soal dengan skala tinggi (Jufri, 2015). Hubungan antara level literasi matematika dengan kelompok kompetensi literasi matematika yang dikembangkan oleh PISA adalah soal literasi matematika level 1 dan level 2 merupakan soal yang cukup dikenal oleh siswa dengan operasi matematika yang sederhana untuk mengukur kompetensi Reproduksi, soal literasi matematika level 3 dan level 4 dengan soal yang membutuhkan interpretasi siswa karena situasi yang diberikan tidak dikenal atau bahkan belum pernah dikerjakan oleh siswa untuk mengukur kompetensi Koneksi dan soal literasi matematika level 5 dan level 6 merupakan soal dengan skala tinggi yang mengukur kompetensi Refleksi (Setiawan, Dafik, \& Lestari, 2014).

Saat ini kemampuan literasi matematis siswa masih rendah. Diketahui dari hasil penelitian PISA (Program For International Students Assesment) untuk kemampuan literasi matematika pada tahun 2015 dengan peringkat ke 63 dari 70 negara yang dievaluasi. Sejalan dengan hasil penelitian (Wijaya, Heuvel-panhuizen, Doorman, \& Robitzsch, 2014) yang menyatakan bahwa siswa di Indonesia mengalami kesulitan dalam memecahkan soal matematika PISA yang berbasis konteks dan mengubahnya menjadi masalah matematika. Penelitian yang dilakukan oleh (Khoirudin, Setyawati, \& Nursyahida, 2017) menemukan bahwa siswa dengan kemampuan matematis rendah hanya mampu menyelesaikan soal level 1.

Salah satu faktor pendukung terkait kemampuan literasi matematika adalah gaya belajar (Breen, Cleary, \& Shea, 2009). Gaya belajar yang digunakan akan membuat siswa merasa terbantu dalam menyerap informasi sehingga memudahkan siswa tersebut dalam proses pembelajaran dan berkomunikasi. Setiap orang mempunyai gaya belajar sendiri-sendiri dan tidak dapat dipaksakan untuk menggunakan gaya belajar yang seragam (Edriati, Hamdunah, \& Astuti, 2016). Dalam pembelajaran di kelas akan ditemukan sebagian siswa menulis materi yang disampaikan oleh guru ketika proses pembelajaran berlangsung. Ada juga beberapa siswa yang fokus mendengarkan materi yang disampaikan oleh guru kemudian siswa menulis materi setelah dijelaskan oleh guru tersebut. Beberapa siswa berjalan ke meja temannya yang dianggap pintar dan meminta tolong kepada temannya tersebut untuk menjelaskan materi yang sudah dijelaskan oleh guru. Dengan perbedaan gaya belajar yang dimiliki siswa maka sebaiknya dalam proses pembelajaran seorang guru harus mengetahui gaya belajar siswa dan menyampaikan materi sesuai dengan gaya belajar yang dimiliki siswa. Dengan mengetahui gaya belajar siswa, guru dapat mengarahkan mereka untuk belajar sesuai dengan gaya belajar yang mereka miliki sehingga dapat dengan mudah menerima pelajaran dan dapat meningkatkan hasil belajarnya (Widayanti, 2013).

Hasil penelitian yang dilakukan oleh (Akbar, Sappaile, \& Djadir, 2015) menemukan perbedaan kemampuan literasi matematika siswa dengan gaya belajar yang berbeda. Sama halnya dengan hasil penelitian (Sari, Adam, Kodirun, \& Busnawir, 2019) yang menemukan perbedaan kemampuan literasi matematika siswa dengan gaya belajar yang berbeda dalam menyelesaikan soal literasi berdasarkan konteks Quantity, Space and Shape serta Change and Relationships. Hasil penelitian (Haryono, 2011) menemukan bahwa siswa dengan gaya belajar Kinestetik mendapatkan hasil belajar rata-rata yang lebih baik dari pada siswa dengan gaya belajar Visual dan Auditorial. Sedangkan hasil penelitian yang dilakukan oleh (Syawahid \& Putrawangsa, 2017) diperoleh bahwa 
kemampuan literasi matematika siswa dengan gaya belajar Auditorial berada pada level 4. Siswa dengan gaya belajar Visual berada pada level 3 dan siswa dengan gaya belajar Kinestetik berada pada level 4.

Berdasarkan hasil penelitian yang telah dilakukan oleh peneliti sebelumnya, maka dilakukan penelitian lebih lanjut mengenai kemampuan literasi matematika ditinjau dari gaya belajar siswa. Penelitian ini juga dilakukan untuk mendeskripsikan kemampuan literasi matematika berdasarkan kompetensi literasi matematika ditinjau dari gaya belajar, namun dibatasi pada aspek konten literasi matematika yang digunakan yaitu konten ruang dan bentuk.

\section{METODE}

Penelitian ini menggunakan metode penelitian deskriptif dengan pendekatan kualitatif yang bertujuan untuk mendeskripsikan kemampuan literasi matematika berdasarkan kompetensi literasi matematika ditinjau dari gaya belajar siswa. Penelitian ini dilakukan di SMA Negeri 1 Lubuk Basung dengan subjek penelitian siswa kelas XII MIA 3.

Instrumen penelitian yang digunakan adalah angket gaya belajar dan tes kemampuan literasi matematika yang akan diujikan pada 32 siswa kelas XII MIA 3 SMA Negeri 1 Lubuk Basung. Wawancara juga dilakukan terhadap siswa setelah tes kemampuan literasi matematika. Angket gaya belajar terdiri dari 36 pertanyaan dengan 12 pertanyaan mengarah kepada gaya belajar visual, 12 pertanyaan mengarah pada gaya belajar auditorial dan 12 pertanyaan mengarah pada gaya belajar kinestetik. Tes kemampuan literasi matematika berupa soal esai dari level 1-level 6 yang telah divalidasi oleh pakar literasi matematika dan pakar materi serta telah memenuhi validitas isi yang memadai berdasarkan hasil perhitungan validitas isi dengan rumus formulasi Aiken's $\mathrm{V}$ dalam (Hendryadi, 2017) yaitu

$$
\begin{aligned}
& V=\frac{\sum S}{[n(c-1)]}, S=R-L o \\
& \text { dengan: } \\
& \mathrm{V} \quad \text { : Validitas yang dicari } \\
& \mathrm{LO} \quad: \text { Angka penilaian validitas yang terendah } \\
& \mathrm{C} \quad \text { : Angka penilaian validitas tertinggi } \\
& \mathrm{R} \quad \text { : Angka yang diberikan oleh penilai/pakar } \\
& \mathrm{S} \quad \text { : Hasil dari pengurangan angka yang diberikan oleh pakar - angka penilaian validitas } \\
& \mathrm{n} \quad \text { yang terendah } \\
& \mathrm{n} \text { Jumlah Panel ahli atau pakar }
\end{aligned}
$$
Tabel 1.

Soal tes kemampuan literasi matematika pada konten ruang dan bentuk dapat dilihat pada

\section{Tabel 1. Soal tes kemampuan literasi matematika}

$\begin{array}{ll}\text { Level 1 } & \begin{array}{l}\text { Perhatikan gambar di samping. Seorang anak akan } \\ \text { menghias langit-langit saung (seperti pada gambar di } \\ \text { samping) dengan menggunakan lampu hias LED. } \\ \text { Ukuran saung tersebut memiliki tinggi } 4 \text { meter serta } \\ \text { lebar dan panjang saung tersebut adalah } 3 \text { meter dan } \\ 4 \text { meter. Apabila panjang kabel lampu hias LED } 50 \\ \text { meter, apakah anak tersebut dapat membuat hiasan } \\ \text { lampu dilangit-langit saung dengan menghubungkan } \\ \text { setiap sudut langit-langit saung yang berhadapan dan } \\ \text { melewati titik tengah pada } \\ \text { langit-langit } \\ \text { saung }\end{array} \\ \text { tersebut? }\end{array}$


Level 2

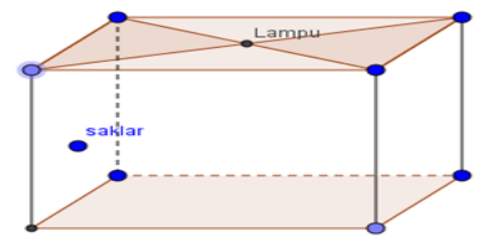

Sebuah ruangan pertemuan berukuran panjang 12 meter dan lebar 10 meter. Di langit-langit ruangan terdapat lampu yang letaknya tepat di tengah langitlangit atap ruangan. Pada dinding sebelah kiri terdapat saklar yang letaknya tepat di tengah-tengah dinding. Berapakah jarak saklar ke lampu apabila tinggi ruang belajar tersebut 6 meter?

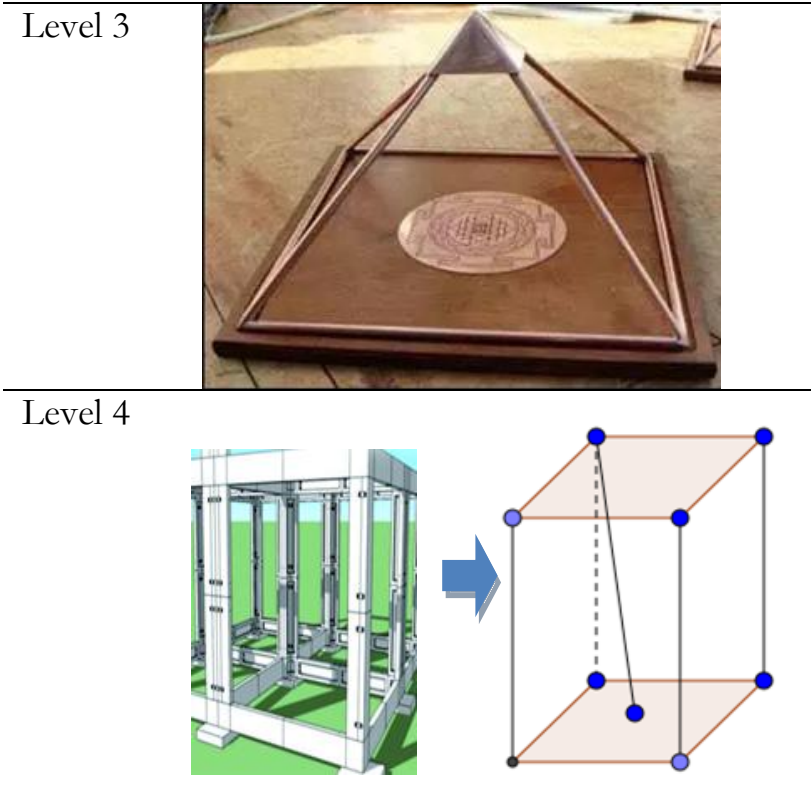

Miniatur di samping akan di cat pada setiap rusuk dari puncak ke setiap sudut alasnya. Ukuran miniatur tersebut memiliki panjang rusuk alas $8 \mathrm{~cm}$ dan tinggi miniatur $4 \mathrm{~cm}$. Satu kaleng cat minyak ukuran paling kecil dapat digunakan untuk mengecat rangka kayu 5 $\mathrm{cm}$. Berapa kaleng cat minyak yang diperlukan untuk dapat melapisi setiap rusuk yang menghubungkan puncak dengan ke 4 sudut alas?

Seorang buruh bangunan akan menyelesaikan sebuah gudang seperti gambar di samping. Kerangka bangunan di samping memiliki panjang dan tinggi berturut-turut adalah $6 \mathrm{~m}$ dan $8 \mathrm{~m}$. Agar bangunan tetap kokoh,buruh bangunan tersebut memasangkan kayu penyangga dari salah satu sudut ke tengah bangunan. Untuk 1 meter kayu biaya yang dikeluarkan adalah sebesar Rp.12.000. Apabila diberikan uang sebesar Rp.100.000, dapatkah buruh bangunan tersebut membeli kayu penyangga?

Level 5

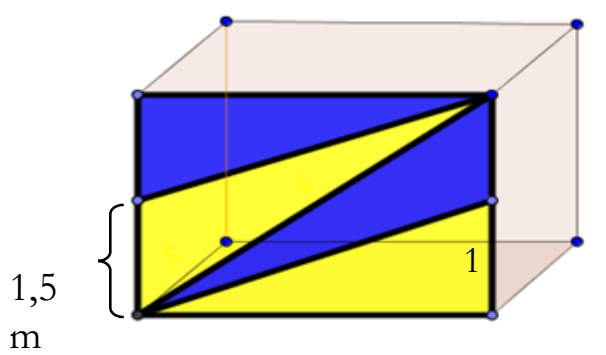

Diketahui sebuah ruangan pertemuan berukuran panjang 12 meter dan lebar 8 meter. Pada satu sisi dinding ruangan tersebut akan dibuatkan grafiti seperti pada gambar di samping. Untuk setiap garis pada grafiti akan diberikan cat piloks berwarna hitam. Apabila 1 kaleng cat piloks dapat digunakan untuk mengecat garis pada grafiti sepanjang 1 meter. Maka, berapa kaleng cat piloks yang dibutuhkan untuk membuat grafiti tersebut?

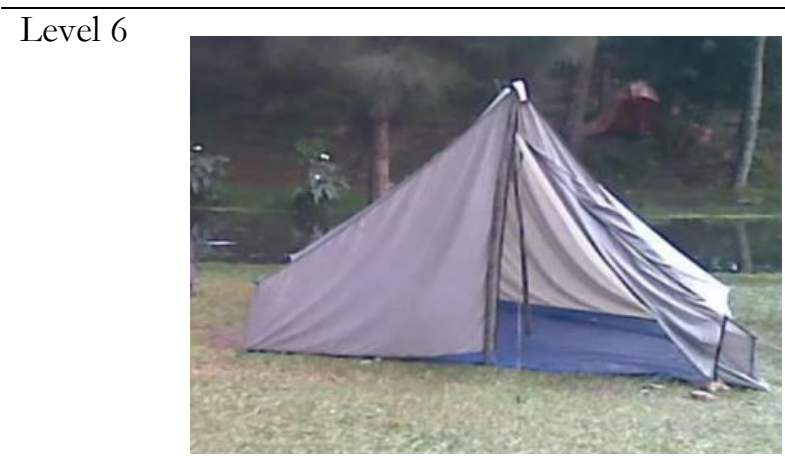

Sebuah tenda yang dipasang memiliki panjang alas yang berbentuk persegi sebesar $4 \mathrm{~m}$. Agar tenda tersebut dapat berdiri tegak, akan dipasangkan sebuah kayu tepat pada puncak tenda ke alas, dengan panjang kayu sebesar $2 \mathrm{~m}$. Setelah dipasang ternyata masih dibutuhkan tiang penyangga agar tenda lebih tegak, sehingga dipasangkan tali pengikat dari titik puncak tenda ke pancang yang dipasang tepat pada pintu masuk tenda. Apabila diikatkan tali dari titik alas ke tali yang menghubungkan titik puncak ke pancang berapakah panjang tali yang dibutuhkan? 
Teknik pengumpulan data pada penelitian ini dilakukan dengan cara memberikan angket gaya belajar, melakukan tes kemampuan literasi matematika dan wawancara. Teknik analisis data berupa analisis data angket gaya belajar, analisis tes kemampuan literasi matematika dan analisis data hasil wawancara. Analisis data angket gaya belajar dilakukan dengan menjumlahkan nilai setiap aspek. Nilai tertinggi setiap aspek menyatakan kecenderungan gaya belajar siswa. Hasil tes kemampuan literasi matematika siswa dianalisis secara deskriptif berdasarkan gaya belajar. Data hasil wawancara dianalisis secara kualitatif. Cara menganalisis data kualitatif terdiri atas 3 tahap yaitu 1) Reduksi data yang merupakan bentuk analisis yang memuat menggolongkan, membuang yang tidak perlu dan mengorganisasikan data mentah yang diperoleh dari lapangan. 2) Penyajian data yang telah direduksi yang akan disajikan secara tertulis, yang sudah diorganisir dan dikategorikan sehingga mempermudah untuk menarik kesimpulan. 3) Penarikan kesimpulan berupa memberi makna dan penjelasan berdasarkan data yang telah disajikan (sugiyono, 2013).

\section{HASIL DAN PEMBAHASAN}

\section{Hasil}

Hasil analisis angket gaya belajar menghasilkan pengkategorian gaya belajar yang dominan maupun yang tidak dominan terhadap subjek penelitian. Hasil tes gaya belajar menunjukkan bahwa siswa memiliki gaya belajar yang berbeda-beda. Gaya belajar siswa yang dominan di kelas tersebut adalah visual, auditorial dan kinestetik. Hasil tes gaya belajar dapat dilihat pada Tabel 2.

Tabel 2. Data hasil tes gaya belajar

\begin{tabular}{lc}
\hline Gaya Belajar & Jumlah Siswa \\
\hline Visual & 12 \\
Auditorial & 10 \\
Kinestetik & 7 \\
Visual-Kinestetik & 2 \\
Visual-Auditorial & 1 \\
\hline
\end{tabular}

Hasil analisis tes kemampuan literasi matematika siswa dengan gaya belajar visual menunjukkan bahwa kemampuan literasi matematika siswa dominan berada pada level 2, 3 dan 4 dengan kompetensi reproduksi dan koneksi. Hasil tes kemampuan literasi matematika siswa dengan gaya belajar visual dapat dilihat pada Tabel 3.

Tabel 3. Hasil tes kemampuan literasi matematika siswa gaya belajar visual

\begin{tabular}{cccc}
\hline NO & SISWA & LEVEL & $\begin{array}{c}\text { KOMPETENSI KEMAMPUAN LITERASI } \\
\text { MATEMATIKA }\end{array}$ \\
\hline 1 & & Reproduksi \\
\hline 2 & AF & 2 & Reproduksi \\
\hline 3 & SL & 2 & Reproduksi \\
\hline 4 & EL & 2 & Reproduksi \\
\hline 5 & FK & 2 & Reproduksi \\
\hline 6 & NC & 2 & Reproduksi \\
\hline 7 & PD & 2 & Reproduksi \\
\hline 8 & ST & 2 & Koneksi \\
\hline
\end{tabular}




\begin{tabular}{llll}
9 & RE & 3 & Koneksi \\
\hline 10 & GM & 4 & Koneksi \\
\hline 11 & MW & 4 & Koneksi \\
\hline 12 & NM & 5 & Refleksi \\
\hline
\end{tabular}

Hasil analisis tes kemampuan literasi matematika siswa dengan gaya belajar auditorial menunjukkan bahwa siswa dominan mampu menyelesaikan soal literasi matematika level 2 dan 4 dengan kompetensi reproduksi dan koneksi. Hasil tes kemampuan literasi matematika siswa dengan gaya belajar auditorial dapat dilihat pada Tabel 4.

Tabel 4. Hasil tes kemampuan literasi matematika siswa gaya belajar auditorial

\begin{tabular}{cccc}
\hline NO & SISWA & LEVEL & $\begin{array}{c}\text { KOMPETENSI KEMAMPUAN } \\
\text { LITERASI MATEMATIKA }\end{array}$ \\
\hline 1 & RF & 2 & Reproduksi \\
\hline 2 & BL & 2 & Reproduksi \\
\hline 3 & MF & 2 & Reproduksi \\
\hline 4 & IS & 2 & Reproduksi \\
\hline 5 & MR & 2 & Reproduksi \\
\hline 6 & DR & 2 & Reproduksi \\
\hline 7 & AV & 3 & Koneksi \\
\hline 8 & AQ & 4 & Koneksi \\
\hline 9 & NS & 4 & Koneksi \\
\hline 10 & SP & 4 & \\
\hline
\end{tabular}

Hasil analisis tes kemampuan literasi matematika siswa dengan gaya belajar kinestetik menunjukkan kemampuan literasi matematika siswa dominan mencapai soal level 3 dan 4 dengan kompetensi koneksi. Hasil tes kemampuan literasi matematika siswa dengan gaya belajar kinestetik dapat dilihat pada Tabel 5.

Tabel 5. Hasil tes kemampuan literasi matematika siswa gaya belajar kinestetik

\begin{tabular}{cccc}
\hline NO & SISWA & LEVEL & $\begin{array}{c}\text { KOMPETENSI KEMAMPUAN LITERASI } \\
\text { MATEMATIKA }\end{array}$ \\
\hline 1 & AD & 1 & Reproduksi \\
\hline 2 & HS & 3 & Koneksi \\
\hline 3 & FA & 3 & Koneksi \\
\hline 4 & RP & 3 & Koneksi \\
\hline 5 & FH & 3 & Koneksi \\
\hline 6 & RJ & 4 & Koneksi \\
\hline 7 & GJ & 4 & Koneksi \\
\hline
\end{tabular}

\section{Pembahasan}

Hasil analisis gaya belajar pada Tabel 2 di atas ditemukan bahwa siswa yang menjadi subjek penelitian paling banyak memiliki gaya belajar Visual (37,5\%), siswa yang memiliki gaya belajar Auditorial (31,2\%) dan Kinestetik (21,8\%). Hasil penelitian yang dilakukan oleh (Nariyati, Halini, \& BS, 2010) juga menemukan bahwa gaya belajar siswa yang paling dominan yaitu gaya belajar Visual $(40,91 \%)$. Menurut (Fathani, 2016) gaya belajar siswa tidak berlaku tetap dan permanen, 
melainkan suatu kecenderungan. Untuk situasi dan kondisi yang berbeda, bisa saja menuntut seseorang untuk menggunakan satu gaya belajar atau kombinasi dari beberapa gaya belajar. Pada penelitian ini fokus gaya belajar hanya pada tipe gaya belajar Visual, Auditorial dan Kinestetik.

Siswa dengan gaya belajar Visual pada Tabel 3, berada pada kompetensi Reproduksi berjumlah 7 orang siswa dimana ketujuh siswa tersebut hanya dapat mengerjakan soal dengan level 1 dan level 2 dengan benar, hal ini dikarenakan soal level 1 dan level 2 merupakan soal dengan pertanyaan dan konteks yang dikenal serta semua informasi yang relevan tersedia dengan pertanyaan yang jelas, serta siswa mudah menafsirkan dan mengenali situasi dengan konteks yang memerlukan kesimpulan langsung. Siswa yang mencapai kompetensi Koneksi berjumlah 4 orang siswa. Siswa pada kompetensi ini mampu mengerjakan soal level 3 dan level 4 yang merupakan soal yang membuat siswa diminta untuk melakukan prosedur dengan jelas, termasuk prosedur yang memerlukan keputusan secara berurutan, bekerja secara efektif dengan model untuk situasi yang konkret tetapi kompleks yang mungkin melibatkan pembatasan untuk membuat asumsi.

Siswa dengan kompetensi Refleksi berjumlah 1 orang siswa dan mampu menyelesaikan soal level 1, 2, 3 dan 5 dengan benar. Dimana soal level 5 merupakan soal yang menuntut siswa mengembangkan dan bekerja dengan model untuk situasi kompleks, mengidentifikasi masalah, membandingkan dan mengevaluasi dengan tepat strategi pemecahan masalah. Salah satu ciri-ciri siswa dengan gaya belajar Visual adalah siswa menghandalkan aktivitas belajarnya kepada materi pelajaran yang dilihatnya (Hartati, t.t.). Hal ini mungkin menjadi salah satu penyebab siswa dengan gaya belajar Visual lebih banyak mencapai kompetensi Reproduksi, karena soal yang diujikan adalah soal yang baru bagi siswa.

Contoh hasil kerja siswa dengan kompetensi Reproduksi dengan gaya belajar Visual yang diwakili oleh subjek PD disajikan pada gambar 1 dan 2. Hasil kerja subjek PD pada gambar 1 menunjukkan bahwa subjek PD mampu menerjemahkan pernyataan, pertanyaan, objek dan gambar. Ini terlihat pada gambar yang dibuat oleh subjek PD sudah tepat dan benar, sehingga dapat dikatakan subjek PD mampu memenuhi indikator kemampuan komunikasi. Subjek PD dapat mengidentifikasi informasi dan menyelesaikan struktur matematika yang sudah biasa digunakan atau struktur rutin. Ini terlihat dari jawaban subjek PD pada saat mencari panjang FH dan panjang lampu LED, sehingga dapat dikatakan subjek PD mampu memenuhi indikator kemampuan matematisasi. Subjek PD dapat menyajikan kembali suatu objek dari informasi dunia nyata dengan lengkap, sehingga dapat dikatakan subjek PD mampu memenuhi indikator kemampuan representasi. Ini terlihat dari gambar yang sudah sesuai dengan informasi dunia nyata yang direpresentasikan dalam bentuk gambar balok. Subjek PD mampu memenuhi indikator kemampuan penalaran dan argumen dengan menuliskan dan menjelaskan pembenaran bahwa panjang $\mathrm{FH}=\mathrm{GE}=5 \mathrm{~m}$. Subjek PD mampu memenuhi indikator kemampuan memilih strategi dengan menuliskan dan menjelaskan langkah-langkah penyelesaian yang ditemukan oleh subjek PD. Hal ini, terlihat dari jawaban subjek PD yaitu subjek PD membuat gambar terlebih dahulu kemudian mencari panjang FH. Subjek PD dapat menggunakan bahasa simbolis, variabel yang sesuai untuk merepresentasikan masalah dunia nyata dengan benar. Subjek PD dapat mengunakan alat-alat matematika untuk mengenali struktur matematika atau menggambarkan hubungan matematis dengan tepat dan benar seperti yang terlihat pada jawaban subjek PD berupa gambar.

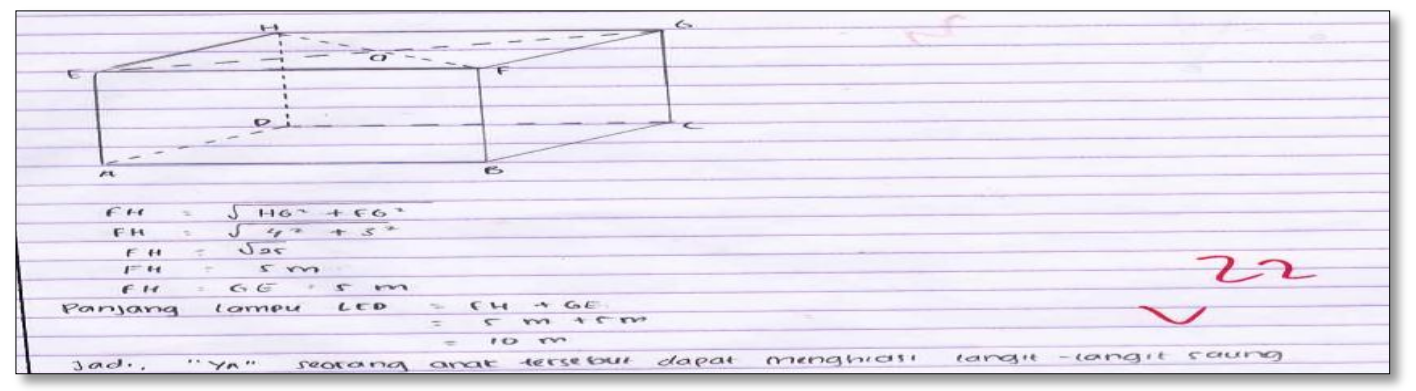

Gambar 1. Jawaban subjek PD soal level 1 
Hasil kerja subjek PD pada gambar 2 menunjukkan bahwa subjek PD dapat menerjemahkan pernyataan, pertanyaan, dengan lengkap dalam bentuk gambar, sehingga dapat dikatakan subjek PD mampu memenuhi indikator kemampuan komunikasi. Subjek PD dapat mengidentifikasi informasi dan menyelesaikan struktur matematika yang sudah biasa digunakan atau struktur rutin. Ini terlihat dari jawaban subjek PD ketika mencari panjang LS, sehingga dapat dikatakan subjek PD mampu memenuhi indikator kemampuan matematisasi. Subjek PD dapat menyajikan kembali suatu objek dari informasi dunia nyata dengan lengkap. Ini terlihat dari jawaban subjek PD mampu merepresentasikan soal ke dalam bentuk gambar, maka subjek dapat dikatakan mampu mencapai indikator kemampuan representasi. Subjek PD mampu memenuhi indikator kemampuan penalaran dan argumen dengan menuliskan serta menjelaskan pembenaran panjang LN dan NS adalah $6 \mathrm{~m}$ dan $3 \mathrm{~m}$. Subjek PD dapat memenuhi indikator kemampuan memilih strategi dengan menuliskan dan menjelaskan langkah-langkah penyelesaian yang ditemukan oleh subjek PD. Subjek PD mampu memenuhi indikator kemampuan dalam menggunakan bahasa, operasi simbolis, formal dan teknis dengan merepresentasikan masalah dunia nyata dengan benar. Ini terlihat dari jawaban subjek PD memisalkan lampu yang berada dilangit-langit ruangan adalah L, saklar dimisalkan dengan S. Subjek PD mampu memenuhi indikator kemampuan menggunakan alat-alat matematika untuk mengenali dan menggambarkan hubungan matematis.

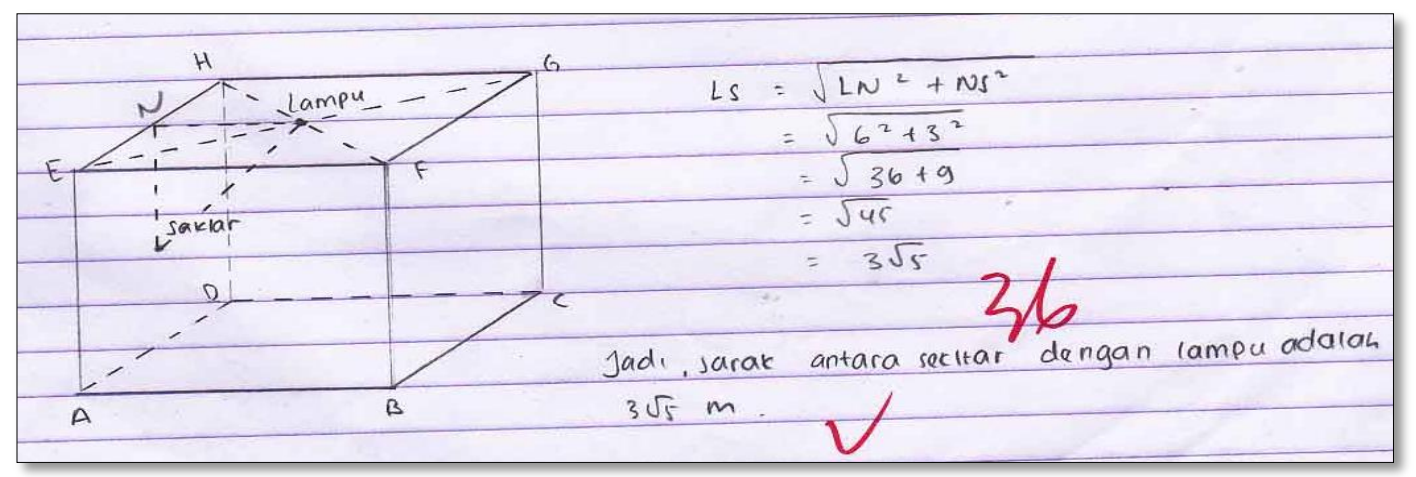

Gambar 2. Jawaban subjek PD soal level 2

Contoh hasil kerja siswa dengan kompetensi Koneksi dengan gaya belajar Visual diwakili oleh subjek GM disajikan pada gambar 3 dan 4. Hasil kerja subjek GM pada gambar 3 menunjukkan bahwa subjek GM hanya mampu memenuhi indikator kemampuan menggunakan alat-alat matematika dengan tepat.

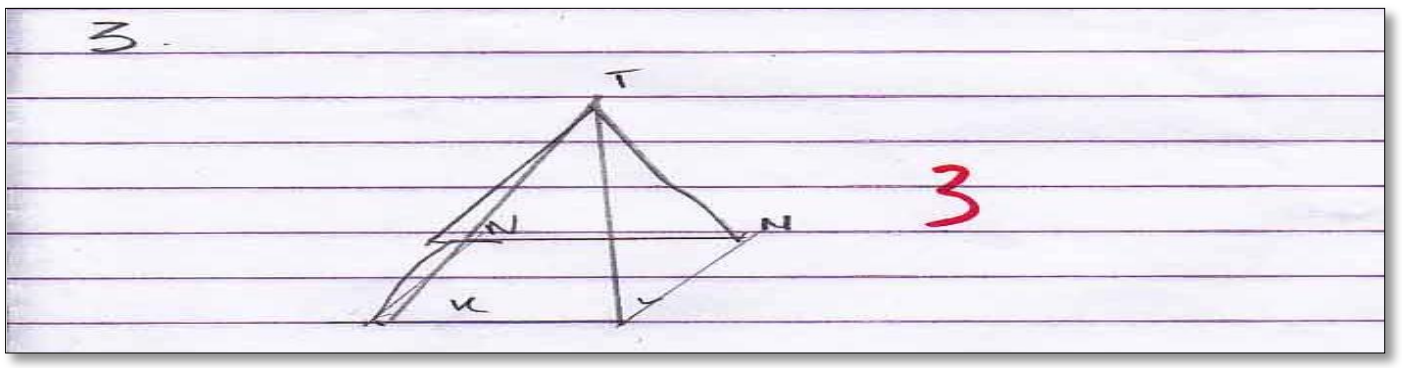

Gambar 3. Jawaban subjek GM soal level 3

Hasil kerja subjek GM pada gambar 4 menunjukkan bahwa subjek GM dapat menerjemahkan pernyataan, pertanyaan, dengan lengkap dalam bentuk gambar, sehingga dapat dikatakan subjek GM mampu mencapai indikator kemampuan komunikasi. Subjek GM dapat mengidentifikasi variabel dan struktur matematika yang menghubungkan representasi yang berbeda dalam masalah dunia nyata dengan benar. Ini terlihat dari jawaban subjek GM mencari panjang DB, DT dan panjang HT, sehingga subjek GM dapat dikatakan mampu mencapai 
indikator kemampuan matematisasi. Subjek GM dapat menyajikan kembali suatu objek dari informasi dunia nyata dengan lengkap. Ini terlihat dari jawaban subjek GM berupa gambar, sehingga dikatakan subjek GM mampu memenuhi indikator kemampuan representasi. Subjek GM dapat menjelaskan pembenaran dengan menuliskan untuk mencari jarak D ke TH perhatikan segitiga DTH siku-siku di D, sehingga subjek GM dapat dikatakan mampu mencapai indikator kemampuan penalaran dan argumen. Subjek GM juga mampu mencapai indikator kemampuan memilih strategi dengan menuliskan dan menjelaskan langkah-langkah untuk mencari panjang panjang $\mathrm{T}$ ke $\mathrm{H}$. Subjek GM dapat memenuhi indikator kemampuan dalam menggunakan bahasa dan operasi simbol yang sesuai. Subjek GM dapat memenuhi indikator kemampuan dalam menggunakan alat-alat matematika untuk menggambarkan serta memudahkan dalam mengenal struktur dan hubungan matematika dengan tepat dan benar. Kondisi ini diperkuat dengan hasil wawancara bahwa subjek GM kesulitan dalam memahami soal level 3 tetapi mudah memahami soal level 4. Subjek GM tidak menjawab soal level 5 dan level 6 karena soalnya susah untuk dipahami dan tidak tau harus mencari apa terlebih dahulu, sehingga dapat disimpulkan bahwa subjek GM berada pada level 4 kemampuan literasi matematika.

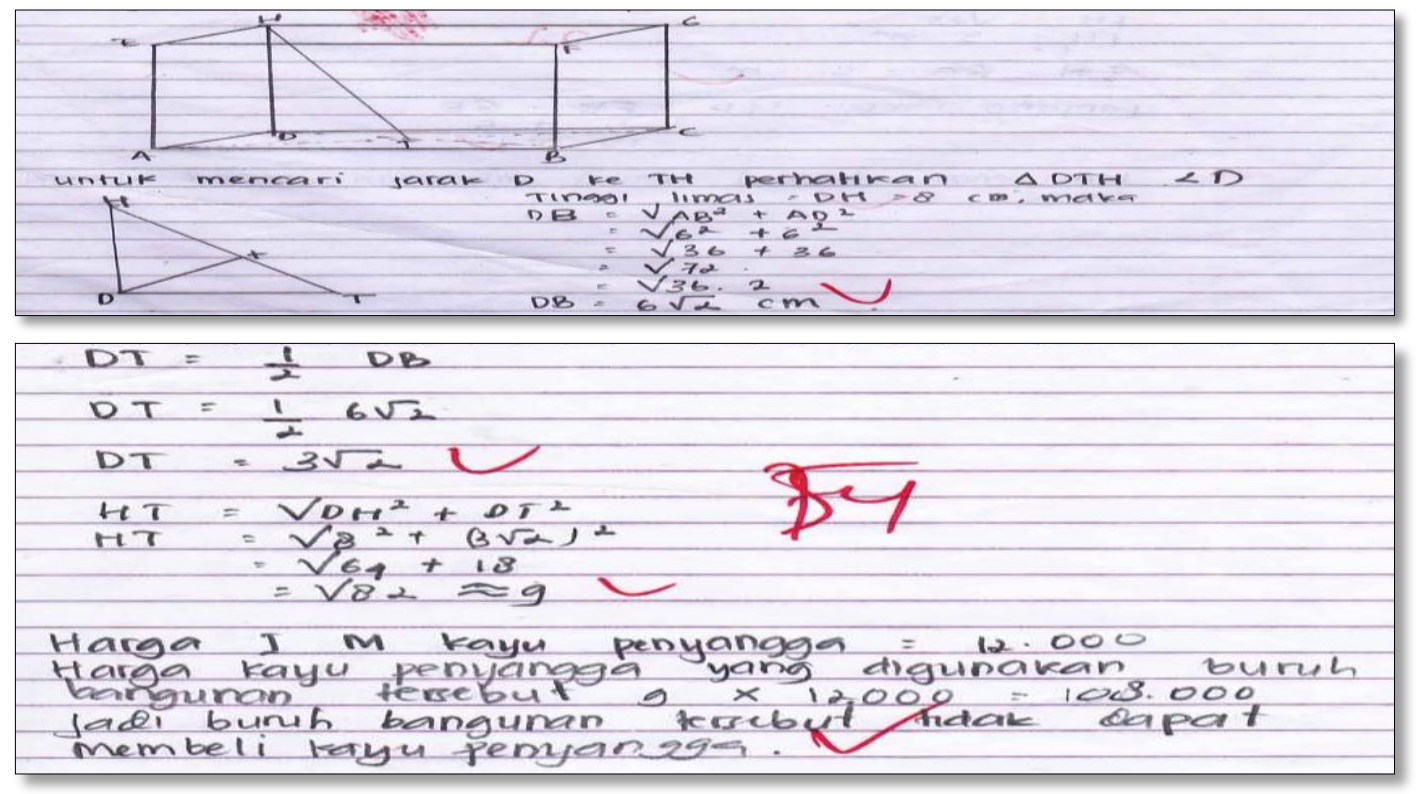

Gambar 4. Jawaban subjek GM soal level 4

Contoh hasil kerja dengan kompetensi Refleksi dengan gaya belajar Visual oleh subjek NM disajikan pada gambar 5. Hasil kerja subjek NM pada gambar 5 menunjukkan subjek NM mampu mencapai kompetensi refleksi. Hal ini ditunjukkan oleh kemampuan komunikasi subjek NM dalam menerjemahkan pernyataan, pertanyaan, dengan lengkap dalam bentuk gambar. Subjek NM dapat mengidentifikasi informasi dan menyelesaikan struktur matematika yang sudah biasa atau rutin, sehingga dapat dikatakan bahwa subjek NM mampu mencapai indikator kemampuan matematisasi. Subjek NM dapat menyajikan kembali suatu objek dari informasi dunia nyata dengan lengkap, sehingga subjek NM dikatakan mampu memenuhi indikator kemampuan representasi. Subjek NM mampu memenuhi indikator kemampuan penalaran dan argumen dengan menuliskan dan menjelaskan pembenaran panjang garis yang dicat warna hitam, sehingga subjek NM dikatakan mampu memenuhi indikator kemampuan penalaran dan argumen. Subjek NM mampu memenuhi indikator kemampuan dalam memilih strategi dengan menuliskan dan menjelaskan langkah-langkah untuk mencari berapa jumlah kaleng cat yang dibutuhkan. Subjek NM mampu memenuhi indikator kemampuan dalam menggunakan bahasa dan operasi simbol dengan tepat. Subjek NM mampu memenuhi indikator kemampuan dalam menggunakan alat-alat matematika untuk menggambarkan serta memudahkan dalam mengenali struktur dan hubungan matematika 
dengan tepat dan benar. Kondisi ini diperkuat dengan hasil wawancara bahwa subjek NM sudah terbiasa dengan soal essai tetapi belum pernah menyelesaikan soal essai yang mengukur kemampuan literasi matematika, soal yang biasa dikerjakan oleh subjek NM berupa soal-soal yang pertanyaan dan informasi dalam soal tersebut lengkap. Karena subjek NM mampu menyelesaikan soal level 5 maka subjek NM berada pada level 5 kemampuan literasi matematika.
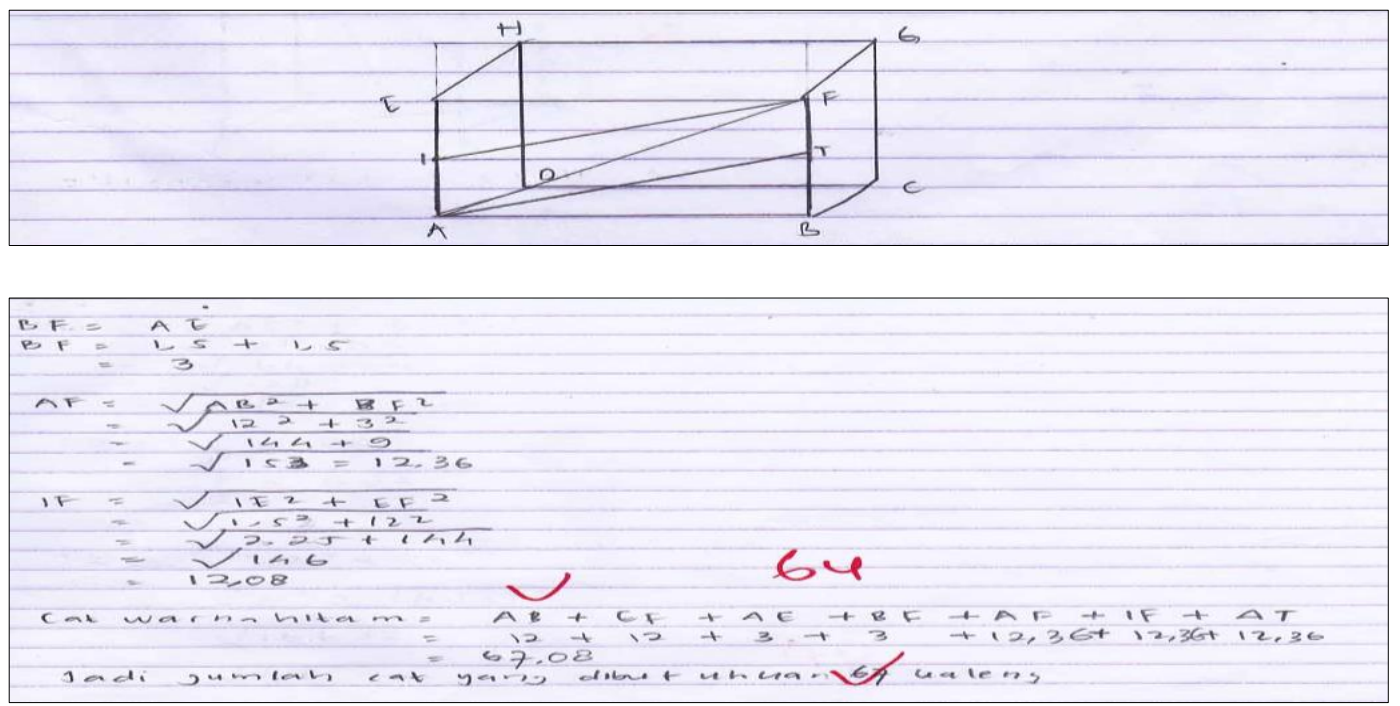

Gambar 5. Jawaban subjek NM soal level 5

Berdasarkan hasil tes kemampuan literasi matematika diperoleh bahwa siswa dengan gaya belajar Auditorial mencapai kompetensi Reproduksi sebanyak 6 orang siswa dan siswa dengan kompetensi Koneksi sebanyak 4 orang siswa. Ciri-ciri siswa dengan gaya belajar Auditorial adalah siswa merasa kesulitan dalam menulis dan siswa belajar dengan mendengarkan serta mengingat yang didiskusikan (DePorter \& Hernacki, 2013). Hal ini yang mungkin menjadi penyebab siswa dengan gaya belajar Auditorial paling banyak hanya mencapai kompetensi Reproduksi, sedangkan terdapat beberapa orang yang sampai pada kompetensi Koneksi dikarenakan ciri-ciri siswa yang mendengarkan dan mengingat apa yang didiskusikan.

Contoh hasil kerja siswa yang memiliki gaya belajar auditorial dengan kompetensi reproduksi diwakili oleh subjek IS yang disajikan pada gambar 6 dan 7. Hasil kerja subjek IS pada gambar 6 menunjukkan bahwa subjek IS mampu menerjemahkan pernyataan, pertanyaan, objek dan gambar, sehingga dapat dikatakan bahwa subjek IS dapat memenuhi indikator kemampuan komunikasi. Subjek IS mampu memenuhi indikator kemampuan matematisasi karena subjek IS dapat mengidentifikasi informasi dan menyelesaikan struktur matematika yang sudah biasa atau struktur rutin. Subjek IS mampu memenuhi indikator kemampuan representasi karena subjek IS dapat meyajikan kembali suatu objek dari informasi dunia nyata dengan lengkap, terlihat dari jawaban subjek IS menggambarkan saung yang akan dihias berbentuk balok. Subjek IS mampu memenuhi indikator kemampuan penalaran dan argumen dengan menuliskan serta menjelaskan pembenaran panjang $\mathrm{FH}=\mathrm{GE}=5 \mathrm{~m}$. Subjek IS mampu memenuhi indikator kemampuan memilih strategi dengan menuliskan dan menjelaskan langkah-langkah untuk mencari panjang lampu LED. Subjek IS mampu memenuhi indikator kemampuan dalam menggunakan bahasa dan operasi simbol dengan tepat. Subjek IS mampu memenuhi indikator kemampuan dalam menggunakan alat-alat matematika untuk menggambarkan serta memudahkan dalam mengenali struktur dan hubungan matematika. 


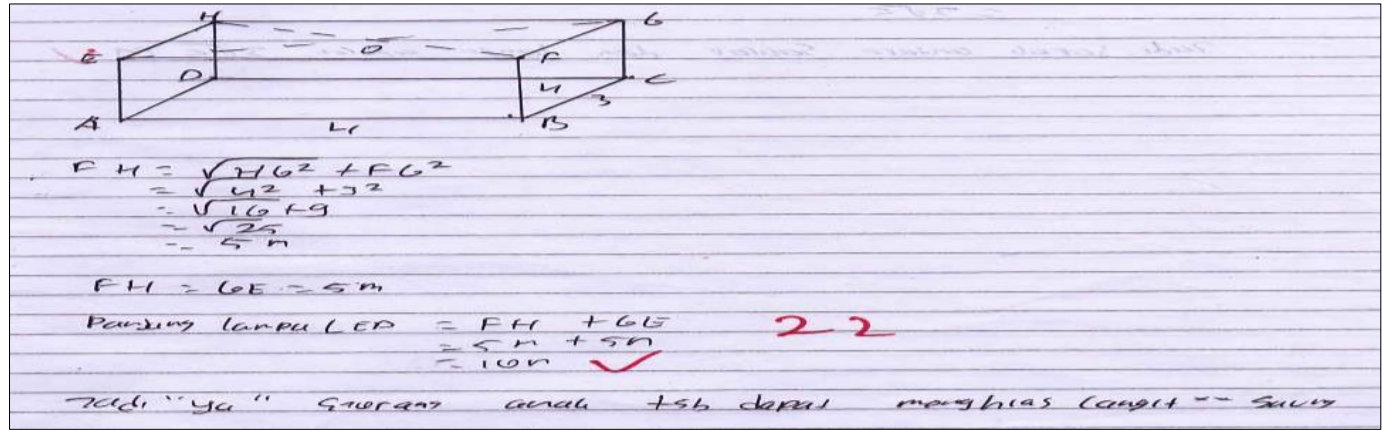

Gambar 6. Jawaban subjek IS soal level 1

Hasil kerja subjek IS pada gambar 7 menunjukkan bahwa subjek IS dapat menerjemahkan pernyataan dan pertanyaan dengan lengkap dalam bentuk gambar, sehingga subjek IS dapat dikatakan mampu memenuhi indikator kemampuan komunikasi. Subjek IS dapat mengidentifikasi informasi dan menyelesaikan struktur matematika yang sudah biasa digunakan atau struktur rutin, sehingga subjek IS mampu mencapai indikator kemampuan matematisasi. Subjek IS mampu memenuhi indikator kemampuan representasi dengan menggambarkan ruangan berbentuk balok dengan dinding sebelah kiri terdapat saklar tepat dipertengahan dinding tersebut. Subjek IS mampu memenuhi indikator kemampuan penalaran dan argumen dengan menuliskan dan menjelaskan pembenaran untuk mencari panjang LS. Subjek IS mampu memenuhi indikator kemampuan memilih strategi dengan menuliskan dan menjelaskan langkah-langkah untuk mencari panjang LS. Subjek IS mampu memenuhi indikator kemampuan menggunakan bahasa dan operasi simbol dengan tepat. Hal ini terlihat dari jawaban subek IS memisalkan L adalah lampu dan S adalah saklar. Subjek IS mampu memenuhi indikator kemampuan dalam menggunakan alat-alat matematika untuk menggambarkan serta memudahkan dalam mengenali struktur dan hubungan matematika. Kondisi ini diperkuat dengan hasil wawancara terhadap subjek IS bahwa subjek IS hanya mampu menyelesaikan soal level 1 dan 2 dimana pertanyaan untuk soal level 1 dan 2 masih jelas dan mudah dimengerti. Sedangkan soal level 3,4,5, dan 6 subjek IS tidak mengerjakan soal tersebut karena kurang paham dengan soal dan tidak tahu langkah pertama yang dilakukan untuk menyelesaikan soal-soal tersebut, sehingga subjek IS dikatakan berada pada level 2 dengan kompetensi reproduksi.

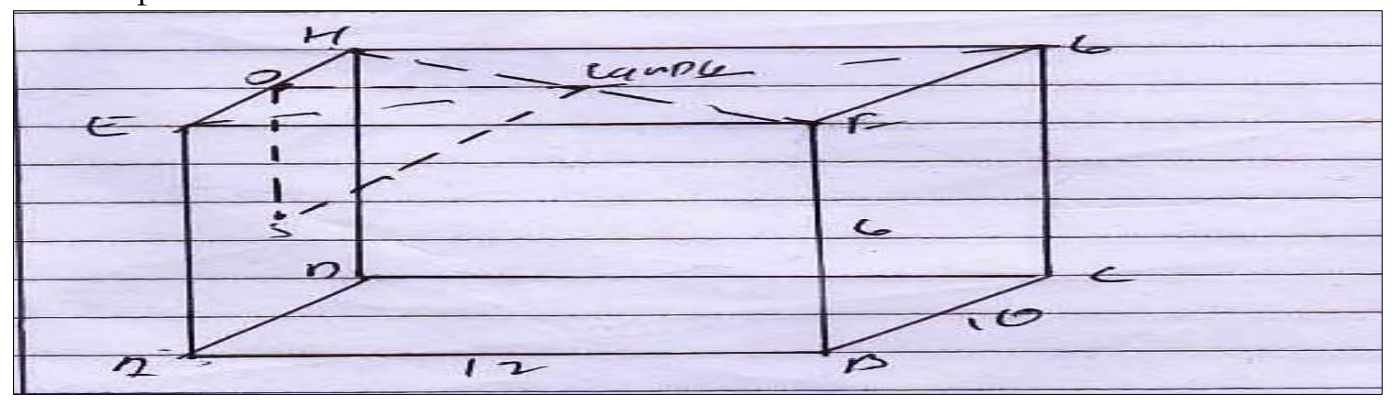

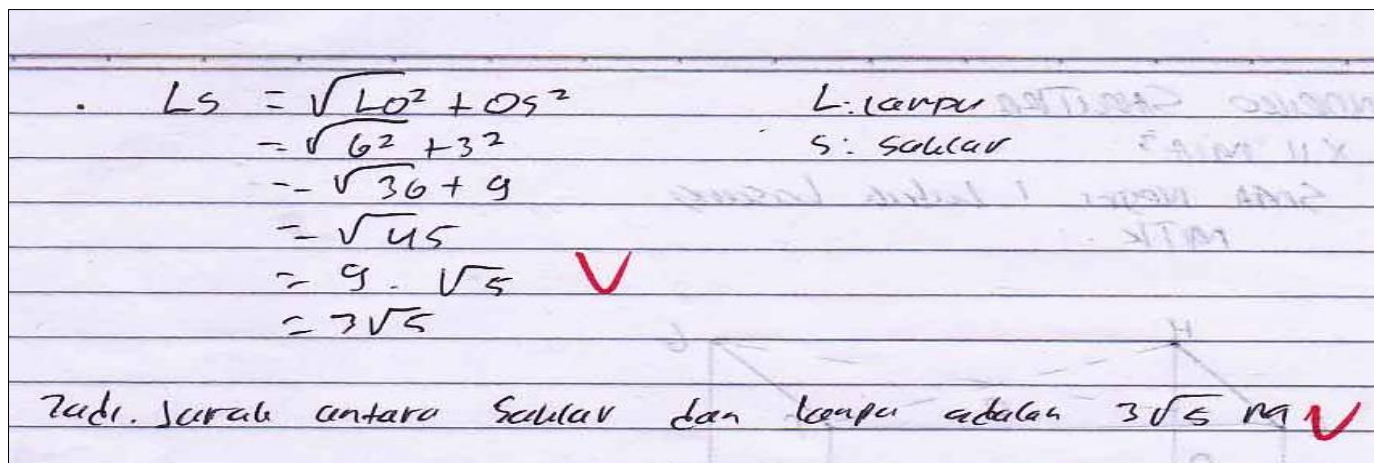

Gambar 7. Jawaban subjek IS soal level 2 
Hasil kerja siswa dengan kompetensi koneksi diwakili oleh subjek AQ, yang disajikan pada gambar 8 dan 9. Hasil kerja subjek AQ pada gambar 8 menunjukkan kemampuan komunikasi subjek AQ dalam menerjemahkan pernyataan dan pertanyaan dengan lengkap dalam bentuk gambar. Subjek AQ dapat mengidentifikasi variabel dan struktur matematika yang melakukan prosedur dengan jelas dengan pemecahan masalah yang sederhana dari masalah dunia nyata dengan benar, sehingga subjek AQ dapat dikatakan mampu mencapai indikator kemampuan matematisasi. Subjek AQ dapat menyajikan kembali suatu objek dari informasi dunia nyata dengan lengkap, sehingga dapat dikatakan subjek AQ mampu memenuhi indikator kemampuan representasi. Subjek AQ mampu memenuhi indikator kemampuan penalaran dan argumen dengan menuliskan dan menjelaskan pembenaran untuk mencari panjang TL $\times$ banyak rusuk. Subjek AQ mampu memenuhi indikator kemampuan memilih strategi dengan menuliskan dan menjelaskan langkah-langkah untuk mencari berapa kaleng cat yang dibutuhkan. Terlihat dari jawaban subjek AQ dari membuat gambar hingga membuat kesimpulan matematika. Subjek AQ dapat menggunakan bahasa dan operasi simbol yang sesuai dengan benar. Subjek AQ mampu memenuhi indikator kemampuan dalam menggunakan alat-alat matematika untuk menggambarkan dan memudahkan dalam mengenali struktur dan hubungan matematika.

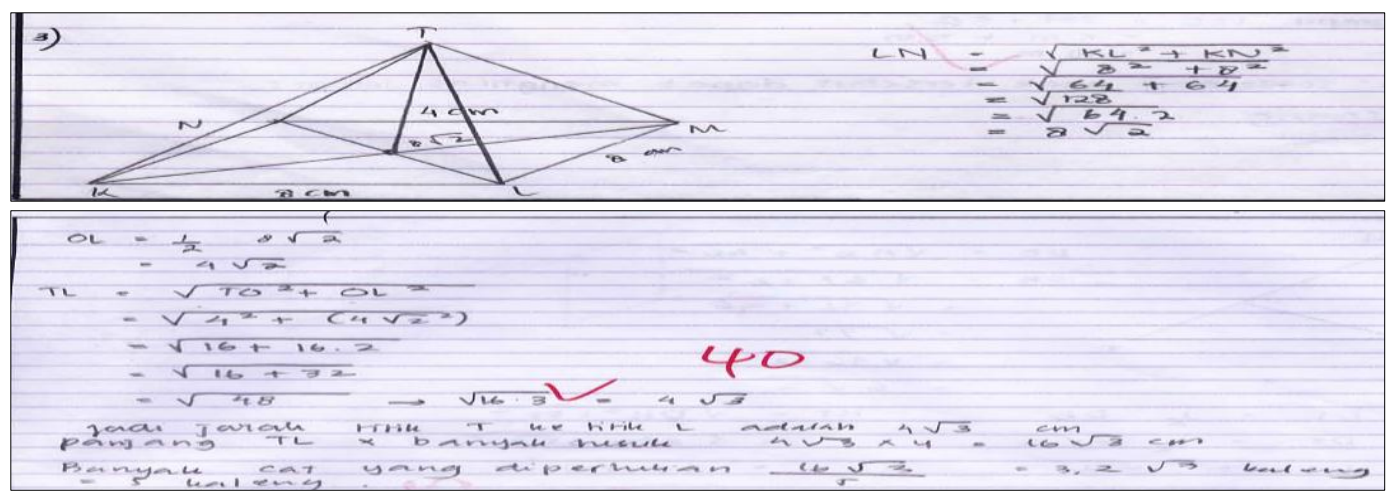

Gambar 8. Jawaban subjek AQ soal level 3

Hasil kerja subjek AQ pada gambar 9 menunjukkan bahwa subjek AQ mampu menerjemahkan pertanyaan, pernyataan, objek dan gambar, sehingga dapat dikatakan bahwa subjek AQ mampu memenuhi indikator kemampuan komunikasi. Subjek AQ dapat mengidentifikasi informasi dan menyelesaikan struktur matematika yang sudah biasa digunakan atau struktur rutin. Ini terlihat dari jawaban siswa memecah gambar untuk memudahkan subjek AQ mencari panjang DB, sehingga dapat dikatakan subjek AQ mampu memenuhi indikator kemampuan matematisasi. Subjek AQ dapat menyajikan kembali suatu objek dari informasi dunia nyata dengan lengkap, sehingga dapat dikatakan subjek AQ mampu memenuhi indikator kemampuan representasi. Subjek AQ mampu memenuhi indikator kemampuan penalaran dan argumen dengan menuliskan serta menjelaskan pembenaran panjang DB dan DT adalah $6 \sqrt{2} \mathrm{~cm}$ dan $3 \sqrt{2} \mathrm{~cm}$. Subjek AQ mampu memenuhi indikator kemampuan memilih strategi dengan menuliskan dan menjelaskan langkah-langkah penyelesaian yang ditemukan subjek AQ. Ini terlihat dari jawaban subjek AQ menuliskan dan menjelaskan dengan baik langkah penyelesaian yang sudah ditemukan secara berurutan. Kemampuan menggunakan bahasa simbolis/formal subjek AQ dapat menggunakan variabel, simbol dengan lengkap. Kemampuan menggunakan alat-alat matematika subjek AQ dapat menggunakan alat-alat matematika untuk mengenali struktur dan menggambarkan hubungan matematika. Hasil wawancara dengan subjek AQ, diperoleh informasi bahwa subjek AQ tidak dapat menyelesaikan soal level 5 dan level 6 karena sulit untuk dipahami. 


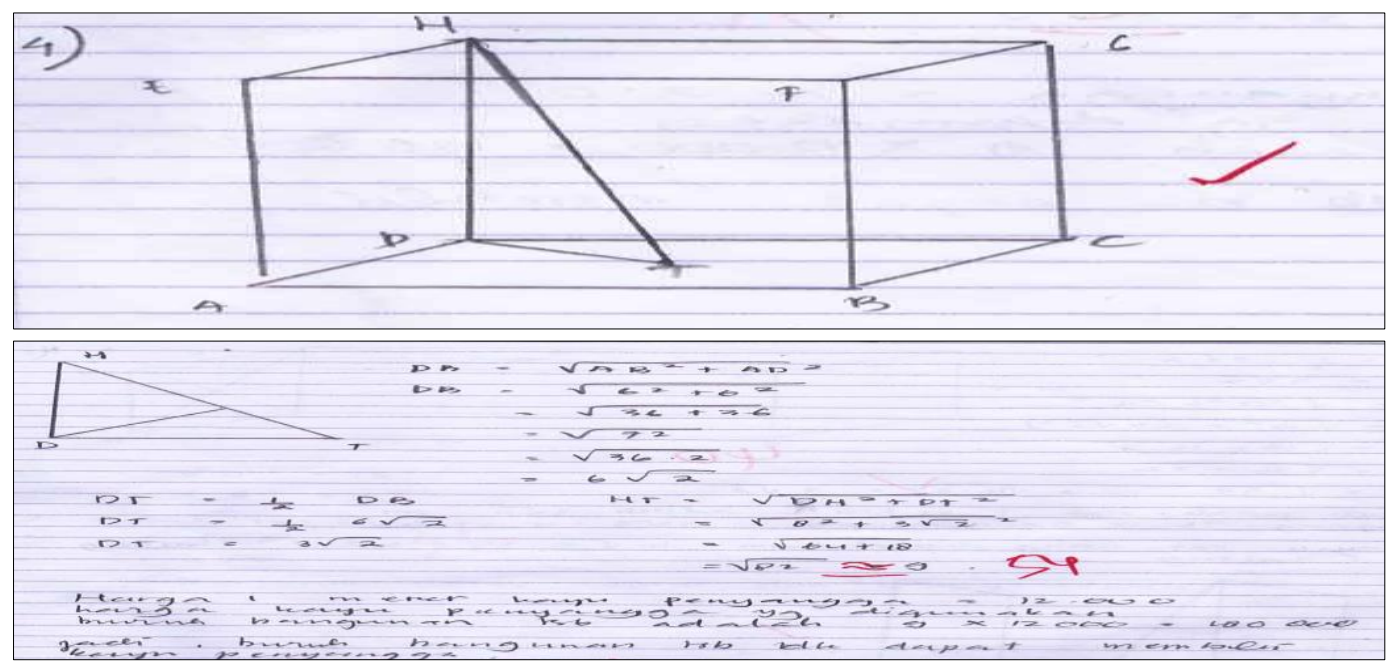

\section{Gambar 9. Jawaban subjek AQ soal level 4}

Berdasarkan hasil tes kemampuan literasi matematika pada konten space and shape terdapat 1 orang siswa berada pada level bawah yaitu level 1 dengan kompetensi reproduksi dari 7 orang siswa dengan gaya belajar kinestetik. Siswa yang berada pada level 3 dan 4 dengan kompetensi koneksi berjumlah enam orang siswa. Siswa dengan gaya belajar kinestetik tidak ada yang mencapai soal level 5 dan 6 dengan kompetensi refleksi. Ciri-ciri siswa dengan gaya belajar kinestetik selalu berorientasi pada fisik dan belajar melalui praktik diduga menjadi salah satu faktor siswa kinestetik banyak mencapai kompetensi koneksi. Hasil penelitian ini relevan dengan hasil penelitian yang dilakukan oleh (Syawahid \& Putrawangsa, 2017) bahwa siswa dengan gaya belajar kinestetik berada pada level 3 dan level 4 dengan kompetensi koneksi.

Contoh hasil kerja siswa yang memiliki gaya belajar kinestetik dengan kompetensi reproduksi diwakili oleh subjek AD yang disajikan pada gambar 10. Hasil kerja subjek AD pada gambar 10 menunjukkan bahwa subjek AD dapat menyelesaikan soal level 1 dengan benar dan memenuhi semua indikator pada kemampuan literasi matematika. Subjek AD mengerjakan soal level 2 tetapi ada indikator yang belum terpenuhi diantaranya adalah kemampuan representasi. Pada kemampuan representasi siswa dituntut untuk dapat merepresentasikan kembali suatu objek dari informasi dunia nyata dengan lengkap. Subjek AD tidak mampu memenuhi indikator kemampuan penalaran dan argumen karena tidak menjelaskan apa yang dimaksud LS, Li dan iS pada rumus untuk mencari LS. Subjek AD tidak mampu memenuhi indikator kemampuan dalam menggunakan bahasa dan operasi simbol, karena subjek AD tidak menyimpulkan hasil akhir. Kemampuan menggunakan alat-alat matematika subjek AD belum lengkap, subjek AD tidak membuat posisi saklar dan lampu untuk memudahkan dalam menyelesaikan soal level 2 tersebut. Kondisi ini diperkuat dengan hasil wawancara terhadap subjek AD bahwa subjek AD tidak mengerti dengan soal level 3, 4, 5, dan 6. Subjek AD hanya mampu menyelesaikan soal level 1 dengan pertanyaan yang mudah.

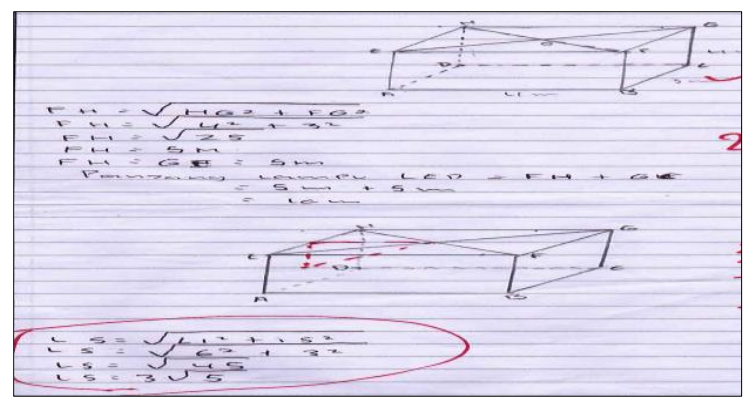

Gambar 10. Jawaban subjek AD soal level 1 dan 2 
Hasil kerja siswa dengan kompetensi koneksi diwakili oleh subjek RJ yang disajikan pada gambar 11 dan 12. Hasil kerja subjek RJ pada gambar 11 menunjukkan bahwa subjek RJ hanya membuatkan gambar tetapi tidak menyelesaikan soal-soal tersebut. Sehingga kemampuan yang terpenuhi hanya kemampuan menggunakan alat-alat matematika dengan tepat.

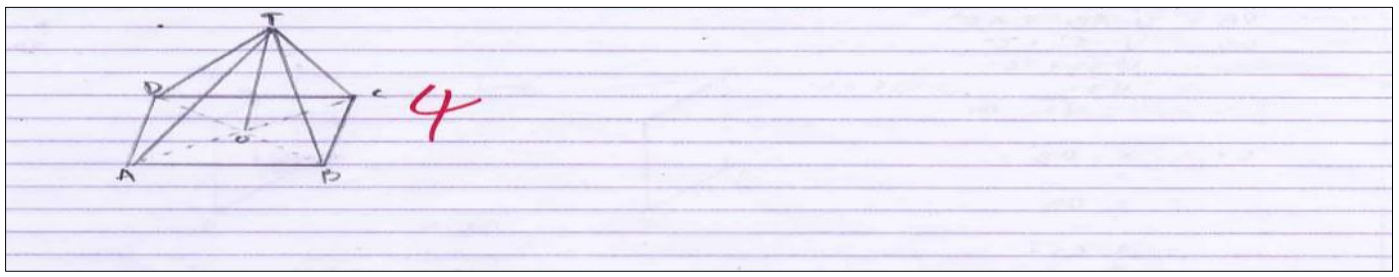

Gambar 11. Jawaban subjek RJ soal level 3

Hasil kerja subjek RJ pada gambar 12 menunjukkan bahwa subjek RJ mampu menyelesaikan soal level 4 dengan semua indikator terpenuhi. Kondisi ini diperkuat dengan hasil wawancara terhadap subjek RJ, diperoleh informasi bahwa subjek RJ kurang paham dengan soal level 5 dan level 6. Subjek RJ tidak mengerjakan soal level 3 tetapi subjek RJ paham dengan soal 3, subjek RJ merasa bahwa soal level 4 lebih mudah dari pada soal level 3.

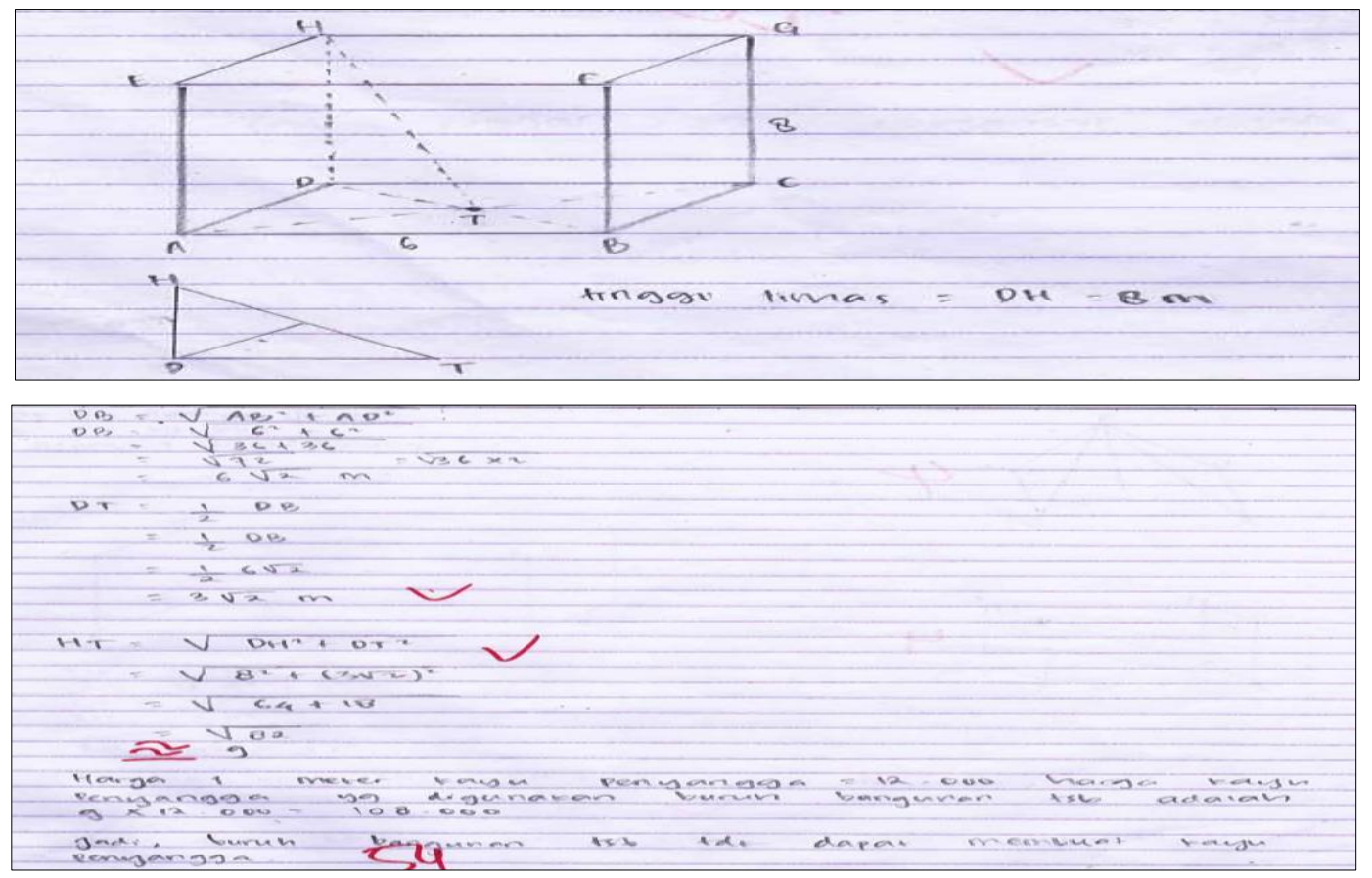

Gambar 12. Jawaban subjek RJ soal level 4

\section{KESIMPULAN}

Berdasarkan hasil penelitian dan pembahasan maka dapat disimpulkan sebagai berikut:

1. Kecenderungan gaya belajar siswa kelas XII MIA 3 dominan memiliki gaya belajar visual, auditorial dan kinestetik, namun terdapat beberapa siswa dengan gaya belajar visual-auditorial dan visual-kinestetik.

2. Siswa dengan gaya belajar Visual lebih banyak berada pada level 2 dengan kompetensi Reproduksi dan 1 orang mencapai level tertinggi dengan kompetensi Refleksi. Siswa dengan gaya belajar Auditorial lebih banyak berada pada level 2 dengan kompetensi Reproduksi tetapi ada 4 orang berada pada level Koneksi. Siswa dengan gaya belajar Kinestetik dengan 
kompetensi Reproduksi sebanyak 1 orang siswa dan kompetensi Koneksi sebanyak 6 orang siswa.

\section{PENGHARGAAN}

Penulis mengucapkan terima kasih banyak kepada: Ibu Lucky Heryanti Jufri, S.Si., M.Pd., Ibu Yulia Haryono, S.Si., M.Pd., Ibu Ratulani Juwita, M.Pd atas masukan dan saran yang diberikan pada penelitian ini.

\section{REFERENSI}

Akbar, A., Sappaile, B. I., \& Djadir. (2015). Profil literasi matematika ditinjau dari gaya kognitif dan gaya belajar pada siswa SMPN 2 Pinrang.

Breen, S., Cleary, J., \& Shea, A. O. (2009). An Investigastion Of The Mathematical Literacy Of First Year Third Level Students In The Republic Of Ireland. International Journal of Mathematical Education in Science and Technology, 40(2).

DePorter, B., \& Hernacki, M. (2013). Quantum Learning: Membiasakan Belajar Nyaman dan Menyenangkan. Bandung: Kaifa.

Edriati, S., Hamdunah, \& Astuti, R. (2016). Peningkatan Prestasi Belajar Matematika Siswa SMK Melalui Model Quantum Teaching Melibatkan Multiple Intelligence. Cakrawala Pendidikan, 395.

Fathani, A. H. (2016). Gaya belajar siswa dalam menyelesaikan masalah matematik ditinjau dari tingkat kecenderungan kecerdasan matematik dan linguistik. Prosiding seminar matematika dan pendidikan matematika 2013, (May 2013).

Genc, M., \& Erbas, A. K. (2019). Secondary Mathematics Teachers ' Conceptions of Mathematical Literacy. International Journal of Education in Mathematics, Science and Technology (IJEMST), 7(3).

Hartati, L. (t.t.). Pengaruh gaya belajar dan sikap siswa pada pelajaran matematika terhadap hasil belajar matematika. formatif, 3(3), 224-235.

Haryono, Y. (2011). Penerapan Perangkat Belajar Kinestetik Dalam Pembelajaran Matematika Berdasarkan Gaya Belajar Siswa SMP DEK Padang. Prosiding Seminar Nasional Matematika UNAND.

Hendryadi. (2017). Validitas Isi: Tahap Awal Pengembangan Kuesioner. Riset Manajemen dan Bisnis (JRMB)UNIAT, 2(2), 169-178.

Jufri, L. H. (2015). Penerapan Double Loop Problem Solving Untuk Meningkatkan Kemampuan Literasi Matematis Level 3 Pada Siswa Kelas VIII SMPN 27 Bandung. LEMMA, II(1), 52-62.

Khoirudin, A., Setyawati, R. D., \& Nursyahida, F. (2017). Profil Kemampuan Literasi Matematika Siswa Berkemampuan Matematis Rendah Dalam Menyelesaikan Soal Berbentuk PISA. Aksioma, 8(2), 33-42.

Nariyati, R. Y., Halini, \& BS, dian A. (2010). Literasi Matematis Siswa Pada Konten Change and Relationship. 1-9.

OECD. (2019). PIS A 2018 Assessment and Analytical Framework. OECD Report.

Sari, D. U., Adam, P., Kodirun, \& Busnawir. (2019). Analisis Kemampuan Literasi Matematis Siswa Kelas VIII SMP Ditinjau Dari Gaya Belajar Dan Perbedaan Gender. Pembelajaran Berpikir Matematika, 4, 23-34. 
Setiawan, H., Dafik, \& Lestari, N. D. S. (2014). Soal Matematika Dalam PISA Kaitannya Dengan Literasi Matematika dan Keterampilan Berpikir Tingkat Tinggi. Prosiding Seminar Nasional Matematika, Universitas Jember, (November), 244-251.

sugiyono. (2013). Metode penelitian kombinasi (Mixed Methods). Bandung: ALFABETA,cv.

Syawahid, M., \& Putrawangsa, S. (2017). Kemampuan literasi matematika siswa SMP ditinjau dari gaya belajar. Beta (Jurnal Tadris Matematika), 10(2), 222-240.

Thomson, S., Hillman, K., \& Bortoli, L. De. (2013). A teacher's guide to PIS A mathematical literacy. Australia: ACER Press.

Widayanti, F. D. (2013). Pentingnya Mengetahui Gaya Belajar Siswa Dalam Kegiatan Pembelajaran Di Kelas. jurnal ERUDIO, 2(1).

Wijaya, A., Heuvel-panhuizen, M. Van Den, Doorman, M., \& Robitzsch, A. (2014). Difficulties in solving context-based PISA mathematics tasks: An analysis of students' errors. the mathematics Enthusiast the authors(s) \& Dept.of mathematical sciencesThe University of montana, 11(3), 555-584. 